\title{
Adolf Meyer and Spain: A Historical Account Gleaned through his Correspondence
}

\author{
Natividad Sánchez \\ Universidad de Sevilla (España)
}

In the early twentieth century, the Swiss-born psychiatrist Adolf Meyer (1866-1950) played a major role in defining and institutionalizing the field of mental hygiene. In addition, he was actively involved in establishing American Psychiatry and Psychology as allied, but professionally and academically independent disciplines. From his highly visible position as professor of psychiatry at Johns Hopkins University and director of the prestigious Henry Phipps Psychiatric Clinic, Meyer assumed a preeminent place in the American Psychological scene. From that position, he also exerted a profound influence internationally. This paper examines Meyer's correspondence with certain Spanish authors in order to glean some insight into the significance of the Spaniards to their American counterparts. It is concluded that Meyer had a deep knowledge of the work of Ramon y Cajal, Nicolas Achúcarro, Gonzalo Rodríguez Lafora, and Emilio Mira. Furthermore, Meyer knew first-hand the political circumstances that forced most of them into exile, and worked with some American initiatives to support Spanish doctors and scientists during and after the Spanish Civil War.

Keywords: Adolf Meyer, Spain, correspondence, Spanish Civil War.

El psiquiatra de origen suizo Adolf Meyer (1866-1950) jugó, a principios del siglo XX, un papel esencial en la definición y la institucionalización de la higiene mental. Asimismo, estuvo activamente implicado en el establecimiento de la psiquiatría y la psicología americanas como disciplinas aliadas pero profesional y académicamente independientes. Desde su puesto como profesor de psiquiatría en la Universidad Johns Hopkins y director de la prestigiosa Clínica Psiquiátrica Henry Phipps, Meyer asumió un lugar preeminente en la escena psicológica americana. También, desde esa posición, ejerció una gran influencia internacional. Este trabajo examina la correspondencia entre Meyer y algunos autores españoles como medio de obtener una primera visión de la significación de los españoles para sus colegas americanos. Se concluye que Meyer conocía en detalle la obra de Ramón y Cajal, Nicolás Achúcarro, Gonzalo Rodríguez Lafora, y Emilio Mira. Pero además, Meyer supo de primera mano las circunstancias políticas que llevaron a casi todos ellos al exilio y colaboró con algunas iniciativas americanas de apoyo a los médicos y científicos españoles durante y después de la Guerra Civil Española.

Palabras clave: Adolf Meyer, España, correspondencia, Guerra Civil Española.

Correspondence concerning this article should be addressed to Natividad Sánchez. Departamento de Psicología Experimental. Universidad de Sevilla. C/ Camilo José Cela S/N. 41018 Sevilla (Spain).E-mail: nsgonzal@us.es 
During the first quarter of the $20^{\text {th }}$ century, psychology and psychiatry in North America had a profound influence on the way the two disciplines came to be defined. Europe's preeminence throughout the $19^{\text {th }}$ century, primarily due to French and German psychiatrists and German psychology, began to shift gradually and inexorably toward the United States (U.S.). This change was not only the result of these disciplines' rapid advancement within the U.S., but the consequence of certain psychologists and psychiatrists relocating to that country for political reasons, or in response to the call of opportunity that the new world held for so many young people. Such was the case for Adolf Meyer (1866-1950), Nicolás Achúcarro (1810-1918) and Gonzalo Rodríguez Lafora (1886-1971).

Being two relatively young disciplines, and ones that largely overlap in areas of research and intervention, it is only natural that psychology and psychiatry simultaneously sought out ways to establish their respective identities by delineating disciplinary boundaries between them. During this process, it was sometimes simpler to define boundaries in terms of occupational profiles rather than trying to establish conceptual, academic and research limits. This was even more difficult because in addition to their theoretical friction, they were both vying for acceptance within the rest of the academic community as rigorous, scientific disciplines. It is no surprise, then, that in the early days of psychiatry and psychology, the lines between them were blurred. This was at times advantageous, when not explicitly encouraged by those participating in the demarcation of their respective intellectual boundaries.

Establishing corresponding professional associations for each discipline was a major step in characterizing each one. During the $19^{\text {th }}$ century, several general, scientific institutions were established in the U.S. such as the American Association for the Advancement of Science, founded in Pennsylvania in 1848, and the American Social Science Association, founded in Boston in 1865. Nevertheless, as social, political and academic ${ }^{1}$ change required professionals to become increasingly specialized, there began to emerge disciplinarily and professionallyoriented associations that also limited and controlled membership (Cadwallader, 1992). In response to many scientists' growing dissatisfaction, the more general scientific organizations attempted to establish specialized sections and divisions, but with little success, and it was under these circumstances that disciplinary associations began to proliferate (Sokal, 1992).
In the case of psychiatry, its professional organization arose in 1844 under the name of the Association of Medical Superintendents of American Institutions for the Insane; it later changed its name to the American MedicoPsychological Association in 1892, then to the name it holds today, the American Psychiatric Association, in 1921. It is among the oldest in the U.S., even appearing before the American Medical Association was launched in 1847. As for psychology, the American Psychological Association was founded in July, 1892 at the hand of G. Stanley Hall (see Evans, Staudt Sexton, \& Cadwallader, 1992).

In a similar fashion, departments and department chairs grew out of universities along with laboratories and journals. The number of congresses, scientific meetings and seminars increased within both disciplines. All these institutionalizing forces helped increase psychology and psychiatry's visibility within the rest of the scientific community, and were instrumental in creating discourse about the identity of each field. However, in countries not yet reached by this professionalization, it was also common during this early period for the names of psychologists and psychiatrists to intertwine and overlap. They took on the same problems using similar or identical strategies and tools, sometimes even came up with the same answers, and participated indiscriminately in many types of institutions. Thus, the history of the process of legitimizing psychological and psychiatric discourse turned out to be much less linear and progressive than it may at first appear, at least outside of the context of professionalization.

Certain figures are indispensable to an analysis of the complex interactions between psychology and psychiatry at that time in the U.S.. One such figure is indubitably the Swiss psychiatrist Adolf Meyer (1866-1950).

In some authors' opinion, Meyer was the most prominent and influential American psychiatrist in the first half of the 20th century (Grob, 1983; Leys 1991; Scull, 2005; Scull \& Schulkin, 2009; Shorter, 1997). Born in Switzerland, he graduated from medical school at the University of Zurich in 1892 and that same year, emigrated to the United States. Over the course of his education, he had the opportunity to visit the foremost hospitals and centers in Germany, France and Great Britain. After spending one arduous year in Chicago, where he had arrived enchanted with the idea of building a future in the field of neurology, he was hired as a pathologist by the Illinois Easter Hospital at Kankakee, where he remained for two and a half years. During this early period, he had his first brush with academia at the

1 It was during the last quarter of the 19th century when universities began to proliferate in the USA that resembled European, especially German, universities in that they gave equal importance to education and research, and increasingly focused on postgraduate education. Johns Hopkins University, founded in 1876, Clark University in 1887, and the University of Chicago in 1891, are clear examples of how academic institutions began to require an increasingly high level of specialization. 
University of Chicago, where he held his first teaching position, though it was merely honorary so he did not receive a salary. He taught a course there in neuroanatomy (Winters, 1966). This combination of clinical practice, teaching and research in a university setting would remain a constant throughout his career. In fact, it was the possibility of pursuing both of those aspects that led him, in 1895, to accept a position as Scientific and Clinical Director at the Worcester State Hospital for the Insane (Massachusetts). In this position, and through the direct connection it afforded with nearby Clark University, Meyer was expected to successfully convert the state hospital into an authentic, educational center for the treatment of nervous illnesses (Lief, 1948). In 1902, he was named Director of the Pathological Institute of State Hospitals (New York) and remained in that position until 1910. During this new stage of his career, he never faltered in his dedication to higher education, joining the faculty at Cornell University as professor of psychiatry in 1904.

During those years, Meyer established the basis of his Psychobiology, a holistic, pluralistic and clearly functionalist approach to the study of the mind. His contributions gained recognition when in 1908, he was offered the position as chair of Psychiatry at the prestigious Johns Hopkins University in Baltimore. Included among his duties was to direct the recently constructed Henry Phipps Psychiatric Clinic. Meyer took on both commitments and converted the Phipps clinic into one of the leading centers of its time in psychiatric treatment, prevention, research and education (Sánchez, \& Diaz, 2008).

Meyer knew all the men and women of note in psychiatry and psychology in those days. Additionally, he took it upon himself to seek out contact with anyone whose short but promising career led him to anticipate their future eminence. Meyer came to be a figure of world-wide renown; his influence on British psychiatry was especially large (Gelder, 2003). His job as chair at Johns Hopkins University and his work as director of the Phipps Psychiatric Clinic were probably essential to this recognition (Grob, 1983). Over time, the theoretical and clinical eclecticism that so characterized Meyer's work made his influence of value, less in terms of theory, and more because of its institutionalizing role (Shorter, 1997).

Adolf Meyer is a clear exponent of some authors' difficulty with and unwillingness to limit their scientific activity to a single domain. Undoubtedly, he served the dual task of actively helping define the field of psychiatry, and at the same time incorporating psychology into his view of the psychobiology of man. This can be confirmed by simply viewing the list of psychologists with whom he had written contact, or his extensive correspondence with psychological institutions. A portion of these documents has received previous attention in the body of literature, such as his exchanges with Edward B. Titchener (Leys \& Evans, 1990) and John B. Watson (Ruiz \& Sánchez, 2006).

Within the context of Meyer's tremendous, international relevance to the fields of psychology and psychiatry in his day, we propose to study the prominence of several Spanish authors within the American science scene by analyzing his correspondence. In Spain too, the first decades of the $20^{\text {th }}$ century were essential in defining psychology. It is not our objective here to offer explanations, or our understanding, of the events that were the first steps toward institutionalizing European advancements in the field of psychology; that has been done by more authoritative voices than ours (see Carpintero 2004, Saiz \& Saiz, 1996). Suffice it to say that saturated in the deeply pro-European spirit that swept Spanish intellectualism toward scientific innovation, a distinguished group of scientists migrated from fundamentally research-based medicine, into psychology (i.e.: Simarro, Cajal, Achúcarro, Turró, Lafora, Pi \& Sunyer, Mira, Germain). Their enterprise would be irreparably and irremediably hindered by the Spanish Civil War and its socio-political consequences. Almost half of Spanish university professors were sent into exile (Dosil, 2007). Considering that many Spanish doctorspsychologists belonged to this group, and adding to that the number who were summarily fired for their political beliefs, or against whom reprisals were taken by the regime, it is safe to say that the consequences to Spanish psychological science were catastrophic.

In A. Meyer's papers deposited in the Alan Mason Chesney Medical Archives at Johns Hopkins University, there is ample proof of the Swiss psychiatrist's written exchange with these first Spaniards interested in psychology. Part of this research will aim to analyze this correspondence, determine the context in which it occurred, and try to infer in what esteem Meyer held the Spaniards. Also, their institutional correspondence portrays widespread concern over the political, economic and social conflict surrounding the activity of these major players.

Correspondence with Santiago Ramón y Cajal. “...sending you, my dear colleague, a guarantee of my most sincere friendship" "...et vous recevez très honoré confrère l'assurance de mon amitié très sincère",

Chronologically, the first correspondence Meyer maintained with a Spanish author was with Santiago Ramón 
y Cajal (1852-1934). It was not an extensive exchange -only 3 documents remain from it- but it did convey a deep mutual understanding of each other's professional situations, which differed markedly at that time. Meyer and Cajal met in 1899 and the circumstances surrounding that first encounter tightened the bond between the two men. Cajal and his wife Silveria Fañanás visited the U.S. once during the summer of 1899; it was then that the two met (for more details about Cajal's trip, see Haines, 2007). Santiago Ramón y Cajal was invited by Clark University to give a series of talks with other European experts. Amid many doubts about the political opportunity implied by a trip to the country that had one year prior prevailed over Spain in war, and after going so far as to consult with members of the Spanish government about the trip's advisability, he decided to accept the invitation they had extended.

In June $1899^{3}$, I was deeply engrossed in the aforementioned explanations in the human cerebrum when there reached my hands a courteous invitation from the American University of Worcester (Clark University) a center of higher studies comparable with the Collège de France, to give several lectures regarding my investigations on the cerebral cortex. (...)

I was deeply surprised and perplexed by the receipt of such a missive. I could not understand how a humble Spanish investigator should have been thought of in the United States, a professor belonging to a vanquished and humiliated race.

I was assailed by doubt. Could I reasonable accept such a compromised invitation a few months after the war, when Spain was still quivering with indignation and rancor after the iniquitous robbery of her colonies" (Ramón y Cajal, 1989, p. 484)

Cajal and four other European experts were invited to an event commemorating the tenth anniversary of the founding of Clark University. In addition to Cajal were Émile Picard, professor of mathematics at the University of Paris, Ludwig Boltzmann, professor of theoretical physics at the University of Vienna, Angelo Mosso, professor of physiology at the University of Turín, and August Forel, a former professor of psychiatry at the Unviersity of Zurich and current director of the Burghölzli Asylum. All were carefully picked "as the most eminent men of science available in Europe in their respective areas; for all, this was their first trip to America" (Story \& Wilson, 1899, p.iii).
The idea for this series of commemorative talks came from the president of Clark University's, the illustrious psychologist and educator ${ }^{4}$, Stanley Hall. It began a tradition at the University of celebrating and commemorating decennials with an outstanding series of talks. The best-known in psychology were the conferences that 10 years later brought Sigmund Freud and Carl Jung to the U.S.. Adolf Meyer actively participated in the academic festivities at both anniversary celebrations. Beginning in 1896, he belonged to the Psychology Department at Clark, where he was in charge of students' training in psychiatry. Considered as he was a standout member of the teaching faculty, he was asked to create a detailed description of departmental courses and research, and it was published to celebrate the first event (Meyer, 1899). Ten years later, after he had been named professor of psychiatry at Johns Hopkins University, Meyer was among the conference's distinguished guests. He gave a talk entitled "The Dynamic Factors in Dementia Praecox and Allied Psychoses" and at the event was awarded an honorary degree.

Shifting our attention back to 1899 , before departing to the U.S., Cajal traveled through France and embarked on his trip to New York from Le Havre, where he coincided with three famous, European scientists, including the illustrious Dr. A. Mosso, the great French mathematician M. E. Picard, and the famous Dr. A. Forel ${ }^{5}$.

Needless to say, in such select company, the twelve days of the crossing passed very quickly. Professors Mosso and Forel, with whom I became very intimate during the journey, were revealed to me as the most agreeable people as well as delightful conversationist. In our colloquies on board we discussed everything, divine and human; philosophy, science, art, politics, etc. (Ramón y Cajal, 1989, 485)

Of these newfound friends, Cajal seemed to grow especially close with August Forel. Their interests overlapped tremendously. In his time, Forel was considered a predecessor to the neuronal doctrine championed by Cajal, but he was also known for his studies of the psychology of ants $^{6}$, another interest they had in common. Cajal not only published histological studies of insects, but also made observations about their behavior and sensory capacities (Ramón y Cajal, 1921).

Though he had yet to receive the highest distinction of his career, the 1906 Nobel Prize, Cajal was a universally

3 The date referred to, June of 1899, may not indicate the first time Cajal received word of this invitation. As Haines (2007) suggests, in a letter dated April 2, 1899, Cajal replies to Clark University's rector, Stanley Hall, accepting the invitation but suggesting that the initial check for $\$ 500$ would not be sufficient to cover his expenses.

${ }^{4}$ We include in cursive the terms with which Cajal refers to Stanley Hall in his memoirs (Ramón y Cajal, 1981, p.217).

5 The adjectives that appear in cursive are the qualifiers used by Cajal in his memoirs ([ibid $],$ p.214).

${ }^{6}$ The second of Forel's conferences in Worcester discussed the biology of ants, and got a lot of press coverage. That was despite the fact that Meyer, having discussed hypnotism at his first conference, would have preferred Forel to have presented on alcoholism (see Lief, 1948). 
renowned researcher when he was invited at the age of 47 to be part of this select group of European eminences. Meanwhile, at 33, the young Meyer was still struggling for visibility in the field of American psychiatry. The poverty of that first year in Chicago was far behind him, yet 10 years remained before, in recognition for his work, he would be hired as a professor at Johns Hopkins and direct its psychiatric clinic. In 1899, the two men found each other despite tremendous life and professional distance. The budding friendship between Forel and Cajal helped to close the breach between Cajal and Meyer. Indeed, Forel and Meyer had known one another a long time; Forel was Meyer's mentor in Zurich and had served as director of his doctoral thesis. Mentor and disciple, they had been friends ever since. Meyer seemed to make quite an impression on Cajal:

As far what concerns me personally, however, it would be ingratitude not to mention the attentions and thoughtfulness which I received from Mr. A. Gordon Webster, the distinguished professor of physics, in whose house I had the honor (...) to speak to of Dr. A. Mayer ${ }^{7}$, a fervent admirer and a compatriot of A. Forel, in whose company I enjoyed the pleasure of visiting the principal institutions of public welfare, and particularly a magnificent hospital devoted to the treatment of nervous and mental diseases (ibid., p.495).

The Hospital Cajal referred to was the Worcester Hospital for the Insane, where Meyer was conducting his clinical work, and where he had extensively reorganized the way things were run (Lief, 1948). How well the lady nurses, who were educated with basic medical knowledge, did especially caught the Spaniard's attention.

Carrying on to analysis of the correspondence, the first letter was dated in Madrid April 2, 1900. In the letter, Cajal informs Meyer that a version of his book in French is being prepared. Based on the letter's content, we suspect that during his visit to the U.S., or in some previous correspondence not found among Meyer's papers, they spoke of the possibility of translating some of his work from Spanish into English or German. At the end of the letter, Cajal remarks how invaluable this project was. In the missive, he details his agreement with the French editor Schleicher, expressly indicating the financial percentage he would receive, and that the following condition had to be met: that while he prepared the French edition, neither the English nor the German version would be allowed.

The second document is dated almost thirteen years later. On January 28, 1913, Cajal wrote an affectionate letter to Meyer declining his invitation to the inaugural exercises at the Phipps Clinic:

I would happily accept the task that would be for me, an opportunity to greet you all and renew my friendship with a number of my American colleagues I had the pleasure of meeting during my trip in '98 to Worcester; plus, the years surely do not pass in vain. My health has become more and more fragile and they insist on order and repose.

J'accepterais volontiers une tâche que serait pour moi l'occasion de vous saluer et de renouveler l'amitié de bon nombre de collègues américains dont j'eus le plaisir de connaitre XXX de mon voyage der 98 à Worcester; mais les années ne passent en vain, Ma santé devient de plus en plus chancelante m'imposant l'ordre et le repos.

This letter is reproduced in Figure 1. Cajal was 60 years old at the time. He seizes the occasion to recommend Achúcarro, "who you know well," as his substitute, suggesting that moreover, his work might be closer to Meyer's interests: "He [Achúcarro] is also preparing to present a report about the pathological structure of the neuron as it relates to problems in psychiatry in which you are particularly interested."

"Il [Achúcarro] serait aussi en mesure de faire quelque rapport sur la structure pathologique du neurone en relation avec les problèmes de la psychiatrie, qui vous intéressent tout spécialement." Shortly after this, in a rough draft of a letter from Meyer in February, 1913, he thanks Cajal for his response, laments his absence at the event, and thanks him nonetheless for recommending Achúcarro.

\section{Nicolás Achúcarro and Lund (1880-1918)}

That is how Nicolás Achúcarro came to be invited to represent Spain in the inaugural exercises at the Henry Phipps Psychiatric Clinic. Achúcarro was not unknown to Meyer. His work was already valued and respected by his American colleagues. He arrived in Washington in 1908,

\footnotetext{
7 Cajal had a curious tendency to misspell the names of his American colleagues. For example, he misspelled Stanley Hall's name as Stamley Hale both in his correspondence with Hall (see Haines, 2007) and in his memoirs. Also, in his correspondence with Meyer, he substituted the name Phipps - the patron behind the Psychiatric Clinic at Johns Hopkins - with Phypps (letter from Cajal to Meyer January 22, 1913). Even Meyer's name was not written correctly in his memoirs, instead substituting an "a" in lieu of the first e in his last name, making it Mayer, although in his correspondence with Meyer himself, the vowels were not switched. This Spanish-izing of Meyer's last name (due to pronunciation) was reflected years later, too, in a list of those absent from the International Congress on Psychology in Madrid (see Carpintero \& Lafuente, 2008, where the document appears in appendix C).
} 


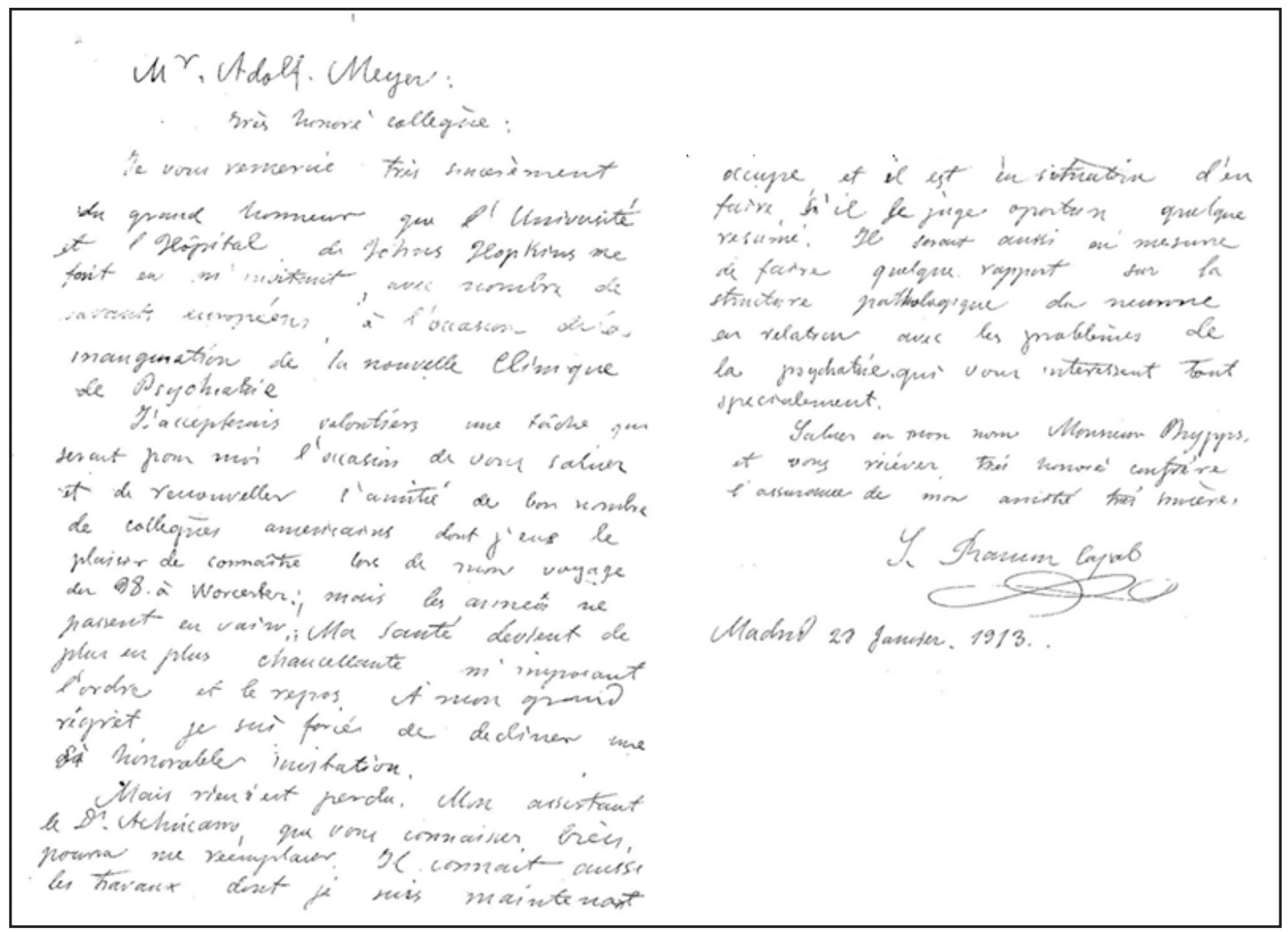

Figure 1. Letter from Santiago Ramón y Cajal to Adolf Meyer dated January 22, 1913. (The Alan Mason Chesney Medical Archives of the Johns Hopkins Medical Institutions, with permission).

accepting a position first offered to Alzheimer thanks to Alzheimer's recommendation that his colleague, "though young, is every bit as capable as I" (cited in Bustamante, 1982). His work in the forefront of the pathological anatomy laboratory at the Government Hospital for the Insane, and the value of his scientific contributions, had earned him great acclaim (García Albea \& Pérez Trullen, 2003).

In fact, it was not the first time since returning to Spain in 1910 that Achúcarro had been invited to the United States. The year before, he had participated in events marking the inauguration of the Fordham University Clinic, accompanied, among others, by Carl Jung. This visit, during which he received an honorary doctorate, was covered in the New York Times:

To celebrate the new era in scientific medical study in Fordham University including the opening of the $\$ 200,000$ building for the clinic recently established an the inauguration of an extension course in the science of nervous and mental diseases, the university last night conferred five honorary degrees, two in absentia, on distinguished scientists who are participating in this new work. (...) the men honored with degrees are eminent specialists who had been delivering a series of lectures at the university. They are: Dr. Head, London; Dr. Horatio Robinson Storer, New York; Dr. Nicolás Achúcarro, Madrid; Dr. Karl Jung Zurich, Switzerland, who were made doctors of law, and Dr. Gordon Holmes, London who was made a doctor of science. (The New York Times, 1912, Septembre 12)

On that occasion at least, Meyer and Achúcarro had the opportunity to meet in person according to a new note in the press that appeared September 13 about a dinner that was part of the celebrations (The New York Times, 1912, September 13).

Though Meyer had the custom of archiving rough drafts of all the letters he sent, there is no record of this invitation in his archives. Nevertheless, Achúcarro was apparently invited and from early on, they were counting on his participation in the Phipps inaugural exercises. In a rough draft of an extensive letter (with no date) written to Janet to invite him to the exercises, too, Meyer himself 


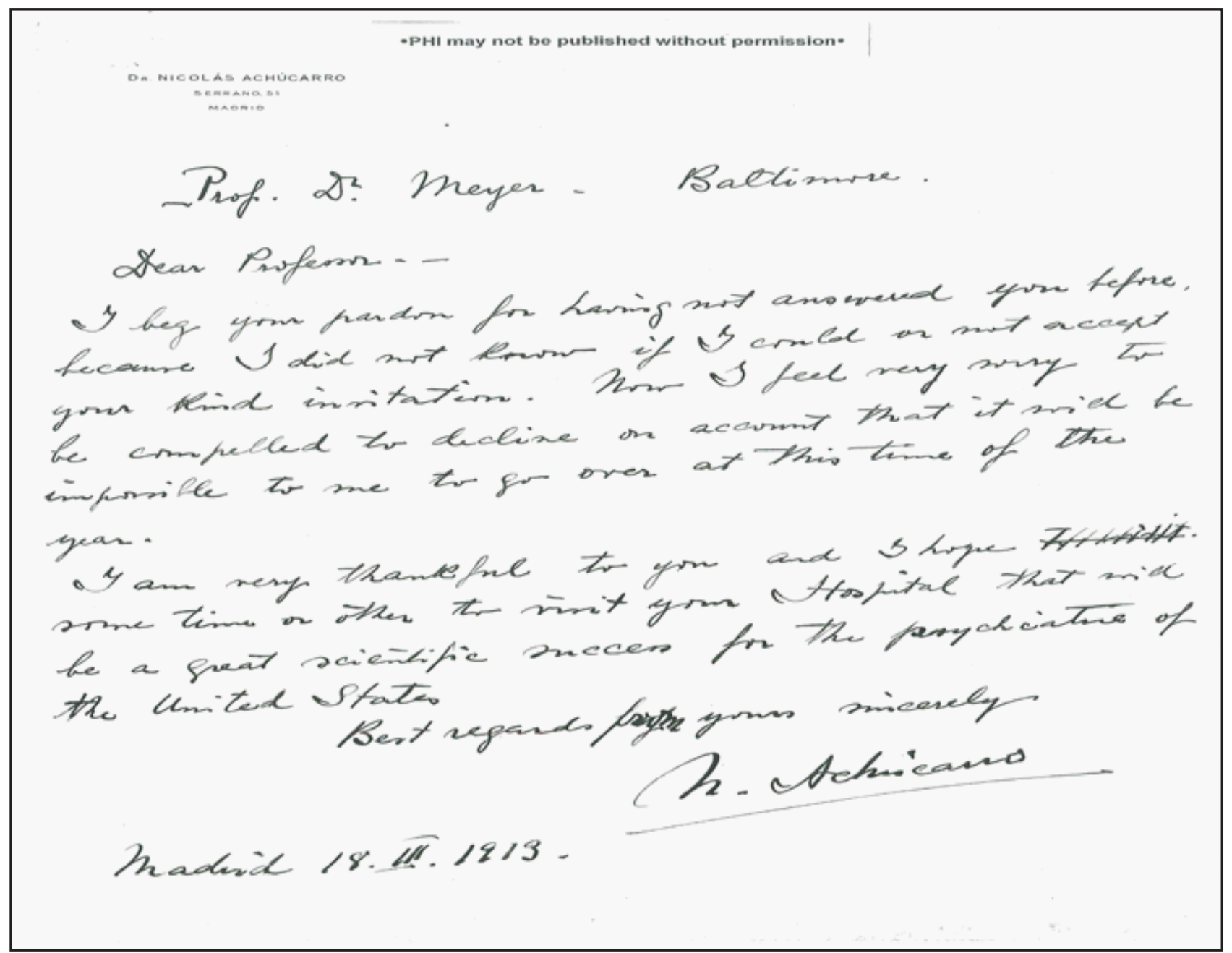

Figure 2. Letter from Nicolás Achúcarro to Meyer dated March 18, 1913. (The Alan Mason Chesney Medical Archives of the Johns Hopkins Medical Institutions, with permission).

confirms that Achúcarro would be participating: "The following colleagues have accepted our invitation: Mr. and Mrs. Bleuler from Zurich, Mr. and Mrs. Heilbronner from Utrech, Mr. Achúcarro from Madrid (in lieu of Mr. Cajal), Mr. Rossi from Sassari, Sir William Osler, Mr. McDougall, and Mr. Mott." Even Science alluded to the Spaniard's participation in a brief note in April, 1913.

However, this disciple of both Cajal and Alzheimer was ultimately unable to make the trip, which is clear from the one document archived: a letter from Achúcarro to Meyer. In this brief note, sent from 51 Serrano St. and dated the $18^{\text {th }}$ of March, 1913, Achúcarro directly indicates it would be impossible for him to attend the Phipps inauguration, but does not provide any reason as to why. The letter is reproduced in Figure 2. In all likelihood, before the letter reached Meyer's hands - which would not have occurred until early April - word had already been sent to the scientific press indicating his attendance; thus, Science reported his participation.
"Dr. Meyer is so anxious to join Dr. Lafora (...)" Gonzalo Rodríguez Lafora (1886-1971)

Adolf Meyer also had the opportunity to meet and interact with Achúcarro's successor in Washington, Gonzalo Rodríguez Lafora. Among the documents compiled in Meyer's archives, not a single letter from this Spaniard remains. Only two rough drafts remain, each pertaining to a letter Meyer sent Rodríguez Lafora; and there was a brief exchange concerning his recommendation that the Spanish doctor be accepted as a member of the American Neurological Association (ANA).

Regarding that matter, on October 3, 1941, Meyer received a letter from Louis Casamajor, an influential figure in New York circles of neurologists and psychiatrists (Grob, 1983), reminding him of the need to write to the ANA Secretary about Lafora's nomination. Ten days later, Meyer wrote said letter of recommendation to Henry Riley at the Neurological Institute in New York. In January, 1942, 
Lafora became a member of the association; only months later, in May, he also joined the American Psychiatric Association, (González Cajal, 1988). The fact that Meyer and Lafora knew each other personally, and that Meyer appreciated his work, is easily inferred from the rough draft of a letter dated November 7, 1923 that writes:

I had hoped last summer on a hasty trip to Europe to be able to visit you and Professor Ramon y Cajal but the time proved to be too crowded. I had hoped to renew personal contact, and specially to make sure that the publications from your laboratory would get into our hands. I do not know why they are not listed among the medical journals in the international book market, but my importing firm, G. E. Stecher \& Company, state that they can not place the order. I should be under great obligations to you if what is available of the Bol. De la Soc. Espa de Biol. Jg, 9 (1921) and the Rev. Trimest. Micrographica (complete) would be sent to us by parcel post as promptly as possible (...)"

It was on this trip during the summer of 1923 when Adolf Meyer had the occasion to meet another Spaniard: Emilio Mira y López; we will discuss this in greater detail later. While Lafora was in exile in Mexico during the summer of 1938, the two men met on a trip that brought him to New York. On October 25, 1938, a letter sent from Dr. Meyer's office to the Secretary of the Spanish Embassy, Fernando de los Ríos, indicated that:

Dr. Meyer is so eager to get together with Dr. Lafora and the rest of the group over lunch that he has made arrangements for someone else to cover his class Wednesday. Therefore, he will be present at the luncheon. I hope this overdue confirmation that he will attend is no inconvenience to you.

\section{The Failed Madrid Congress: Correspondence with José Germain Cebrián (1897-1986)}

In Meyer's archives, there is record of a brief exchange with José Germain, who was Secretary of the ill-fated International Congress on Psychology that was to take place in Madrid in September of 1936 (see, for example, Carpintero \& Lafuente, 2008; Montoro \& Quintanilla, 1982). In a lengthy letter to Meyer dated March 30, 1936, Germain, in addition to describing in depth some organizational details, invites Meyer to participate in a round table discussion on the topic "Hallucinatory Processes and How They Relate to Processes Involved in Belief and Perception." As Carpintero and Lafuente (2008) have suggested, one of the many problems the organization faced was that many of the people they hoped would participate in the Congress either declined to attend or did not respond at all.
The rough draft of Meyer's response, hand-written on the original letter from Germain on April 20, 1936, indicated he was among those declining to participate. José Germain wrote to Meyer in French, but Meyer responded in English. He told the Spaniard:

I regret greatly that the date of the Congress makes it impossible for me to join you this year since my teaching program demands my presence here. I shall look forward to the report although I shall have preferred by far the personal contacts and the visit to your scientific centers and above all the colleagues of Dr. Mira and Dr. Lafora to whom I would like to send my regrets and best regards

\section{An Energetic Fellow (...): Emilio Mira y López (1896-1964)}

We only had access to one document from Meyer's correspondence with Emilio Mira for the writing of this article. In this letter, Mira thanks Meyer for his hospitality during his trip to the United States en route from London to Argentina, where he was to live in exile (see Figure 3).

Meyer and Mira, however, had met long before. During the summer of 1923, July 29th to be precise, Meyer made a note in one of his journals "I had the good fortune of falling in with Dr. E. Mira of Spain." The fortunate occasion took place as a consequence the Meyers' trip to Europe in the summer of 1923 - when he originally intended to visit Lafora and Cajal - "The main interest I had in going to Europe, apart from reopening contact with my numerous personal friends, was naturally the trend of scientific progress, and the two congresses -the physiological and the psychological international meetings, in Edinburgh and Oxford." It was during the 7th International Congress of Psychology, celebrated in Oxford from July 26 through August 2, when Meyer was introduced to Mira. This encounter piqued Meyer's interest in the political situation in Barcelona. Using his difficult, sometimes indecipherable hand-writing, he noted:

He [Mira] is catalan and gave a good description of the conditions in Barcelona. The new catalan language and nationalism, the syndicalist and reactionary forces and the attempts to create a socialist party, the fascist tendencies (without black shirt or organization) ${ }^{8}$ and then about some writers (Felipe Trigo, Ortega y Gasset \& Baroja.

Mira is in Charge of a pscyhotecnic lab. (..) an energetic fellow (even if he refuse to move to see the Norman church)"

Emilio Mira attended the congress accompanied by George Dwelshauvers, a Belgian psychologist who worked as director of the Psychology Laboratory in Barcelona from 1920 to 1924 (see Siguan \& Kirchner, 2001).

${ }^{8}$ The characteristic blue falange shirts did not appear until it was founded in 1933 by Primo de Rivera. 


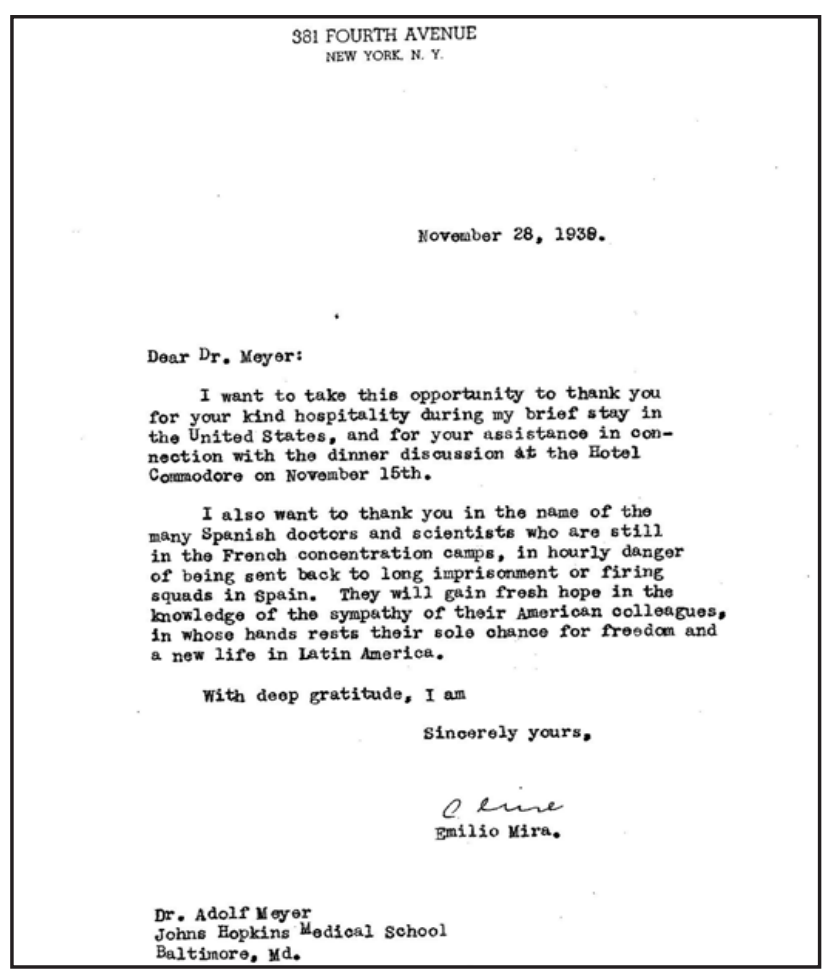

Figure 3. Letter from Emilio Mira to Adolf Meyer on November 28, 1939 (The Alan Mason Chesney Medical Archives of the Johns Hopkins Medical Institutions, with permission).

This is not the time to go into detail about Mira's accomplishments and his work's international acclaim, but suffice it to say that the two men must have had more opportunities to get to know one another over the course of their careers. It is improbable that Meyer would not have attended the meeting of the American Society for the Advancement of Science (Section I-psychology) held in Boston in 1933 at which Mira, Kohler, Spearman and Pieron were in attendance, or that they would not have had some contact when Mira was invited in 1942 by the New York Academy of Medicine to present at the Salmon Memorial Lectures. ${ }^{9}$

Documents Related to the Spanish Civil War: “(...) the Spanish people have fought a heroic fight against rebels and foreign invaders, for independence, democracy and progress" 10

A significant portion of the documents connected to Spain that remain in Meyer's archives relate to the events surrounding the Spanish Civil War and the exile of Spanish intellectuals. It has been suggested previously that the Spanish debate became very quickly internationalized, and that American intellectuals largely supported the Republic (Bandrés \& Llavona, 1996). In fact, the Spanish war was one where reporters - particularly American and British - acquired a prominence not previously seen; writers of repute were at times transformed into war correspondents or documentary film-makers. In this way, the American intellectual class became highly politicized. Shaped by an environment of profound social and economic problems, and fearful of the advance of fascism in Europe, they largely supported those loyal to the republican government.

Not only intellectuals and artists aligned themselves with the Spanish Republic; Americans' reaction in support of it was massive. In addition to their contingent of volunteers - known as the Abraham Lincoln Brigade- around 2,800 men came to Spain to fight; several associations looked for ways to help the democratic Spanish government ${ }^{11}$. Despite the passing of the Neutrality Act of $1937^{12}$, these associations managed to provide money and humanitarian aid, especially medical provisions and food. In addition,

\footnotetext{
${ }^{9}$ Meyer had the honor of presenting at the first installment of the Salmon Lectures in 1933. In 1942, he received a medal as a prize for his professional accomplishments.

${ }^{10}$ Letter from Henry E. Sigerist to Adolf Meyer December 18, 1937.
} 
they initiated a number of propaganda and political campaigns in favor of the Republic, such as lobbying the United States government to lift the trade embargo. As Fox Maura (2009) indicates, though the anti-embargo movement was ultimately unsuccessful, it did succeed in mobilizing the American people in support of the Spaniards' democratic fight. In 1939, 70\% of Americans were against the Neutrality Act and sided with the Republic. Even in the White House, there were discordant voices, not only from the president's wife Eleanor Roosevelt, or the Secretary of the Interior, Harold. L. Ickes ${ }^{13}$; even the Secretary of State, Cordell Hull, was highly critical of it.

One of the most standout, effective and committed associations in support of the Spanish people was the American Medical Bureau to Aid Spanish Democracy, also known as the Spanish Medical Bureau, which grew out of an organization called the American Friends of Spanish Democracy. Its objective: to fund-raise and send material and human aid to Spain. This association's two most important achievements were lifting the embargo on all types of medical supplies, including vehicles, and ensuring that medical volunteers, nurses, ambulance drivers and other sanitation technicians - about 120 people - were legally allowed to enter Spain. Starting in January of 1937, the American State Department stamped the following on its citizens' passports: This passport is not valid for travel to Spain. Thanks to the Spanish ambassador, Fernando de los Ríos, interceding, that was not stamped on the passports of medical personnel traveling to Spain (Fox Maura, 2009).

One of the most prominent figures in science within this organization was the physiologist Walter Bradford Cannon (1871-1945). He not only played the necessary, intellectual leadership role, being as he was a highly renowned scientist, but also supported and participated with dedication every one of the organization's undertakings ${ }^{14}$. Cannon had especially close ties to Spain; two Spanish friends and colleagues had been part of his research team in the laboratory at Harvard: Rosendo Carrasco Formiguera and Jaime Pi-Suñer. When he visited Spain in 1930, they hosted him and introduced him to Juan Negrín, who had an enormous impact on him. He maintained correspondence with all of them, as well as Gregorio Marañón, who he also met while in Spain. Cannon joined the Medical Bureau in October, 1936, and served as President at the national level, and also for the Boston delegation until its disappearance in 1939 (Benison, 1991, Wolfe, Barger \& Benison, 2000).

During the first few months of 1937, several subcommittees were formed to generate medical aid from other professionals: lawyers, social workers, engineers, writers, artists. Psychologists also organized themselves around the Psychologists' Committee of the Medical Bureau to Aid Spanish Democracy. It was rather indecisively presided over by Clark L. Hull, but the driving force behind it was Theodore C. Schneirla (Finison, 1977).

Henry E. Sigerist (1891-1957) was among the most active supporters of the Spanish Republic at Johns Hopkins University. He belonged to the North American Committee to Aid Spanish Democracy, the American Friends of Spanish Democracy, and to the Medical Bureau to Aid Spanish Democracy, and participated quite actively in all of them. A Parisian of Swiss descent, he attended medical school in Zurich. Upon graduating in 1917, he became interested in research on the history of medicine. In 1925, he succeeded Karl Sudhoff as director of the prestigious Medical History Institute in Leipzig, a pioneering institution. He traveled to the United States at the invitation of William $\mathrm{H}$. Welch, director of the Johns Hopkins Medical History Institute, and one year later was asked to take his place. He accepted the offer and moved to Baltimore in 1932 (Fee, 1986, Brown \& Fee, 2003).

Sigerist was a socially and politically dedicated intellectual and like Cannon, he felt particular empathy for the situation in Spain (Martí Ibañez, 1958). In September

\footnotetext{
${ }^{11}$ Some associations tied to the rebels, or nacionales, appeared as well, such as the House of Spain in New York, led by the directors of the Spanish Chamber of Commerce. The American pro-Franco movement was decidedly made up of and led by Catholics (for cases of associations specifically in New York, see McNamara, 2008).

${ }^{12}$ Due to Italy's invasion of Ethiopia in 1935, the U.S. passed a Neutrality Act for fear of again becoming implicated in an international conflict the likes of World War I. This was the first in a series of neutrality acts. The one passed in 1935 assured neutrality in cases of acts of aggression between other countries. Having expired six months after being passed, it was replaced by a new Neutrality Act in 1936 that used the same terms as before, but also prohibited giving credits or loans to countries at war. Neither of the two acts reflected the eventuality of civil war. In January of 1937, while the '36 act was still valid, a joint resolution by the House of Representatives and the Senate explicitly prohibited the selling of arms to Spain. Finally, in May, 1937, an Act was approved that included civil wars and prohibited American boats from transporting goods and passengers to conflict zones.

${ }^{13}$ Harold L. Ickes (1874-1952) acted as Secretary of the Interior for thirteen years, from 1933 to 1946 (the entirety of the Roosevelt administration and part of President Truman's), and was Mary Ickes's brother. She was John B. Watson's first wife.

${ }^{14}$ Cannon had taken on a clear leadership role and was made head of the organization not only because of his distinguished standing in the scientific community, but also for his high level of political commitment and his personal ties to Spain. It was known that in 1934, invited by Pavlov to give a talk at the International Congress on Physiology held in Moscow, he seized the opportunity to launch a harsh attack against fascists meddling in matters of science (Benison, 1991).
} 


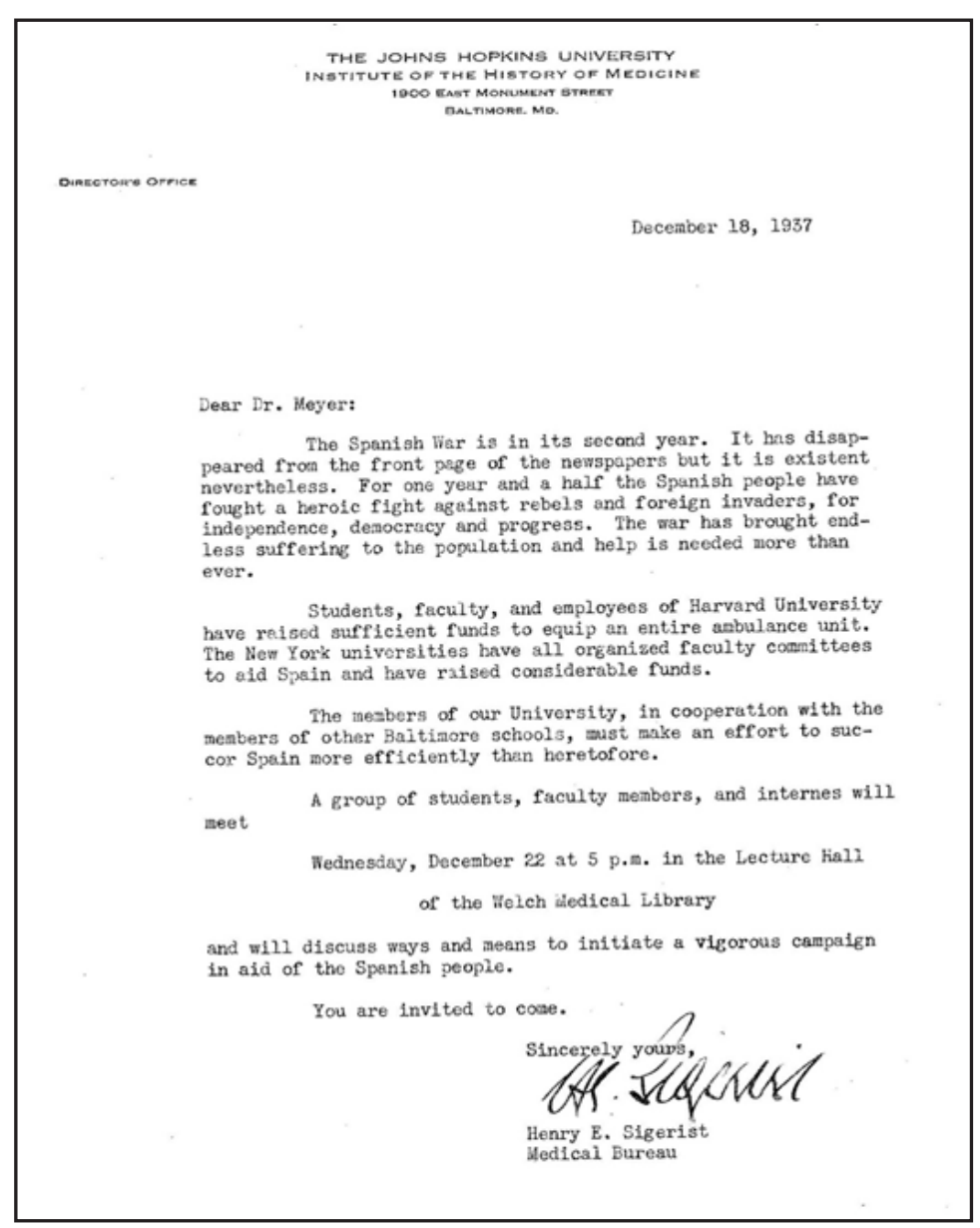

Figure 4. Letter from Henry E. Sigerist to Adolf Meyer on December 18, 1937 (The Alan Mason Chesney Medical Archives of the Johns Hopkins Medical Institutions, with permission)

of 1935 , he attended the $10^{\text {th }}$ International Congress on the History of Medicine, which was celebrated in Madrid while Gregorio Marañón was president of the organization. His political sympathies for the Republic were not only apparent in his active participation in the associations that supported it, but also in his writings and discourse:

These glorious autumn days will remain unforgettable to all who were privileged in attending this gathering. The tragedy that was soon to befall the Spanish people was in the air already and could be perceived by whoever knows how to feel the pulse of the country.(...) Life was gay enough in daytime. But at night the streets assumed the aspect of a besieged city with large detachments of police, infantry and cavalry patrolling the streets. And in the hotel my elevator boy and waiter studied the works of Karl Marx. One year after we had been offered a magnificent banquet in the Alcazar of Toledo, the latter was blown up and the President of the Madrid Congress Gregorio Marañon is now living abroad while we are sending American physicians to help the Spanish people in their struggle for independence (Sigerist, 1939).
His involvement may have been strengthened by the tragedy that befell a member of his own university. Sigerist and Meyer were both probably aware of the dramatic events surrounding the death of José Robles Pazos in 1937. This is especially likely considering that one of Meyer's collaborators, William Horsley Gantt, would have known the story first-hand due his friendship with the writer John Dos Passos, who traveled to Spain in search of news about the Spaniard. José Robles Pazos (1897-1947) was a close friend of Dos Passos as well as his translator; they met in Spain in 1916 and at the time of his death, he was a professor in the Romance Languages Department at Johns Hopkins. He had arrived in Spain in June of 1936 intending to spend the summer and was surprised by the outbreak of civil war. After gaining permission from the academic authorities, he joined the service of the legitimate government, the Republic. He was detained in December of the same year by members of the Soviet secret service and was executed early in 1937 in a dark episode ripe with political intrigue. Two works have recently been published in Spanish that attempt to shed some light on these events, which were 
partially responsible for the rupture of the friendship between the American writers Ernest Hemingway and John Dos Passos (Koch, 2006, Martínez de Pisón, 2005).

In a letter from Sigerist to Meyer written on December 18,1937 , he invites him to attend a meeting at the Welch Library, the library at the Hopkins Medical History Institute, where they would analyze how the university could become more actively involved in the plight of the Spanish republicans. The letter appears in Figure 4. Sigerist's idea was to acquire similar support as universities in New York, as well as Harvard ${ }^{15}$ had achieved. In the first paragraph, he clearly conveys his admiration for the struggle of the Spanish people.

Sigerist says:

Dear Dr. Meyer:

The Spanish War is in its second year. It has disappeared from the front page of the newspapers but it is existent nevertheless. For one year and a half the Spanish people have fought a heroic fight against rebels and foreign invaders, for independence, democracy and progress. The war has brought endless suffering to the population and help is needed more than ever. (...) The members of our University, in cooperation with the members of other Baltimore schools, must make an effort to succor Spain more efficiently than heretofore.

Other actions instigated by Sigerist sought to more directly incite his countrymen's conscience, especially politically-speaking. The following undated letter arrived at Meyer's office from Sigerist's secretary:

A copy of the following message will be sent to Negrin, Prime Minister of the Spanish Republic. Would Dr. Meyer be willing to sign his name to this message?. A copy of this will also be sent to the newspaper-The Sun ${ }^{16}$

"In the present critical situation as evidenced by the bombing of Barcelona we assure the Spanish people of our full sympathy against German and Italian Fascim"

The letter probably refers to the bloody bombing of Barcelona that took place between March 16 and 18, 1938 that claimed the lives of over 4,500 people.

Also among Meyer's correspondence, we found letters exchanged with another, highly distinguished member of this organization, a surgeon from New York by the name of Edward K. Barsky (1897-1975). Barsky was a founder of the Medical Bureau and went to the front line in Spain with the first contingent of medical aid. He departed from New York on January 16, 1937 only days after the first group of 96 Americans had done so, the Abraham Lincoln Brigade $^{17}$ (see Barsky, 2007). By the following year, there were already 117 Americans volunteering as doctors, nurses and ambulance drivers in Spain. Doctor Barsky returned to the United States in 1937 to be the keynote speaker for a national speaking tour that aimed to raise funds and support. During this visit, Barsky had the opportunity to address a convention of the American Psychological Association held late in 1937 in Minneapolis (Finison, 1977). Upon returning to Spain, he assumed control over the International Brigades Sanitation Service, which he managed until international forces withdrew in January, 1939.

After the war, the Medical Bureau restructured its objectives into an effort to help Spanish refugees, changing its name to the Medical Aid Committee for Spanish Refugees; Barsky was its Secretary ${ }^{18}$. This organization formed part of a national association called the Spanish Refugee Relief Campaign, of which the Secretary of the Interior, Harold L. Ickes, was named honorary president. Though Walter Cannon continued to support this organization's endeavors, he was no longer on its front line.

Meyer supported some of this committee's endeavors to assist refugees, and there is a record of that in the remaining documents from his correspondence. Chronologically, his first contact had to do with a visit from Emilio Mira in the fall of 1939 en route to Argentina. The letter is dated October 27, 1939 and in it, Barsky, either overlooking the fact that Meyer knew of Mira, or using a model that was sent out to more than one person who could potentially help, describes the achievements of the "eminent Spanish psychologist and psychiatrist," with "70 titles in the field of psychiatry, and 55 in the field of psychology; among them: (...) chief psychiatrist of the Spanish Republican army." In the letter, he announces a dinner-debate that Walter Cannon would preside over, and in which Mira would discuss the "Psychological Effects of War." The letter solicited his sponsorship, assuring Meyer "your consent involves no other use of your name nor any further demands on you, although we should be greatly honored if you should decide to attend."

15 This was unsurprising since W. Cannon was there.

16 This refers to a Baltimore newspaper, The Baltimore Sun.

17 The first organized contingent left New York on December 26, 1936.

18 In 1942, Dr. Barsky founded the Joint Anti-Fascist Refugee Committee. This active militancy precipitated him and 17 members of the committee's directive council to be investigated and cited by the House of Anti-American Activities Committee. After declining to turn over archives with his collaborators' names for inspection for years, and above all, the list of republicans they had helped (some who were going to receive help were still in Spain), Barsky was sentenced to 6 months in prison. When he left, his medical license was suspended for an additional six months. 


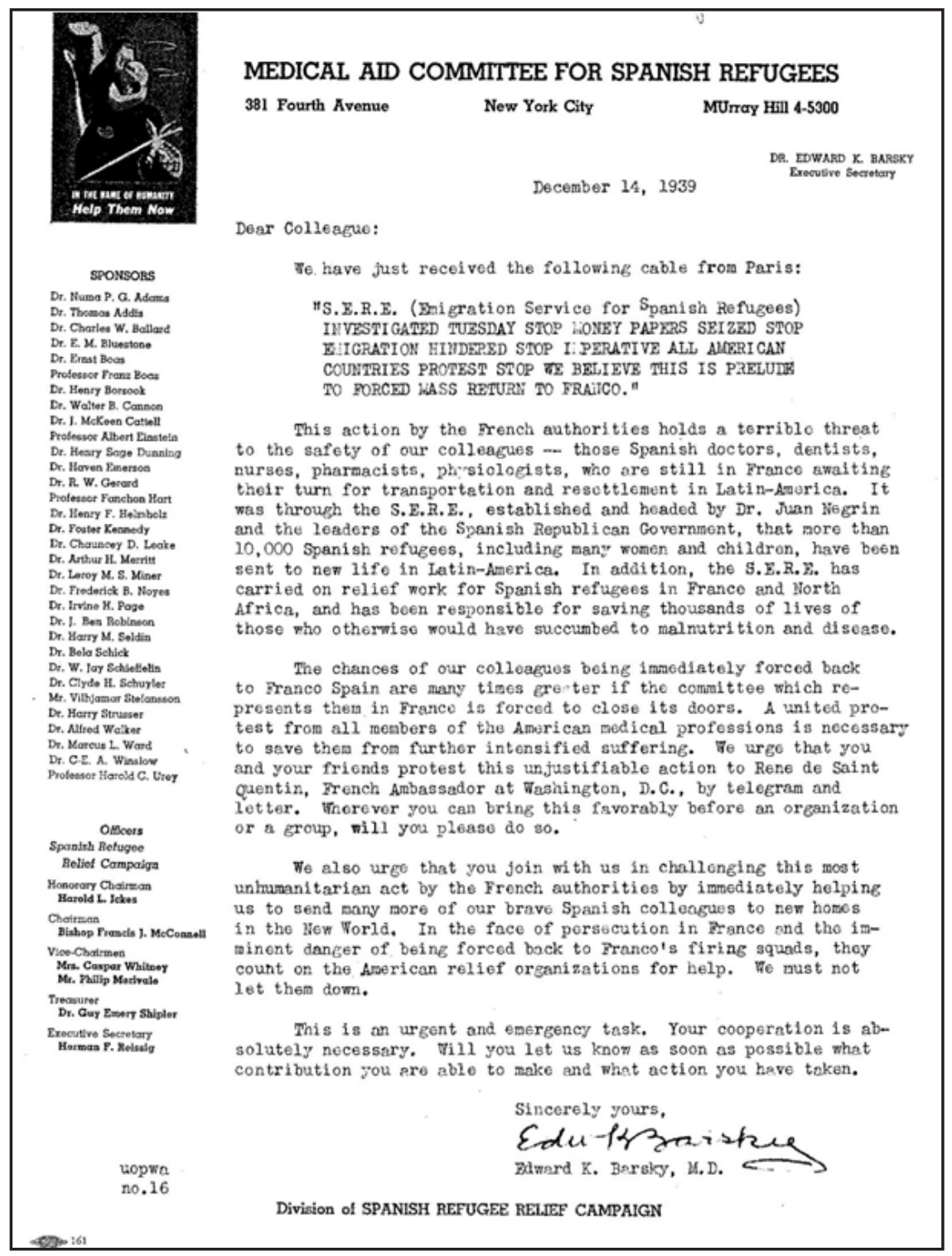

Figure 5. Letter from Edward K. Barsky to Adolf Meyer on December 14, 1939 (The Alan Mason Chesney Medical Archives of the Johns Hopkins Medical Institutions, with permission).

Only three days later, Meyer asked for more information about where and when the event would take place. "I am very glad to hear that Dr. Mira will be given a welcome on his arrival in this country. I have known him since 1923 and I shall be glad to join the number of those who welcome him." In a letter from November 1, Barsky subsequently confirmed that "Dr. Mira arrived yesterday on the "Scythia." We have just made definitive arrangements to hold the dinner at the hotel Commodore, New York, Wednesday, 15 at 7.00 P.M."

Meyer received one more letter related to this event. On November 4, Foster Kennedy, then president of the committee in charge of the event, titled the Psychological Effects of War on Civilians and Military Population, provided further details about the meeting. The letter's final paragraph in particular illustrates the American intellectuals' enormous concern with the international political situation and its future consequences:

Especially, as we are faced with the possibility of a new World War, we must take advantage of every opportunity for a wider understanding of the whole question of Mental Hygiene. The Committee joins me in asking you to attend this important discussion on human behavior under war conditions which, I am sure, will be beneficial in aiding human welfare.

The letter we alluded to previously, dated November 28, 1939 and sent by Emilio Mira to Meyer, thanks the latter for his attendance. In it, Mira takes the opportunity to acknowledge the event's role in supporting Spanish refugees: 
Mira writes:

I also want to thank you in the name of the many Spanish doctors and scientists who are still in the French concentration camps, in hourly danger of being sent back to long imprisonment or firing squads in Spain. They will gain fresh hope in the knowledge of the sympathy of their Americans colleagues, in whose hands rests their sole chance for freedom and a new life in Latin America.

The following letter signed by Barsky on December 14, 1939 - and displayed in Figure 5- without a doubt, must have been much more alarming. In it, he alerts Meyer to the fact that he had received the following telegram from Paris:

S.E.R.E. (Emigration Service for Spanish Refugees) INVESTIGATED TUESDAY STOP MONEY PAPERS SEIZED STOP EMIGRATION HINDERED STOP IMPERATIVE ALL AMERICAN COUNTRIES PROTEST STOP WE BELIEVE THIS IS A PRELUDE TO FORCED MASS RETURN TO FRANCO.

Barsky's letter continues with extreme urgency:

This action by the French authorities holds a terrible threat to the safety of our colleagues -those Spanish doctors, dentists, nurses, pharmacists, physiologists who are still in France awaiting their turn for transportation and resettlement in Latin-America. It was trough the S.E.R.E., established and headed by Dr. Juan Negrin and the leaders of the Spanish Republican Government, than more than 10,000 Spanish Refugees, including many women and children, have been sent to new life in Latin-America.

For this reason, Barsky went on, "We urge that you and your friends protest this unjustifiable action to Rene de Saint Quentin, French Ambassador at Washington, D.C. by telegram and letter." The imperative tone of this call to action was clear. "In the face of persecution in France and the imminent danger of being forced back to Franco's firing squads, they count on the American relief organizations for help. We must not let them down." Accompanying this text was a list of medical professionals who could be relocated to Latin America for 100 dollars, and brief descriptions of their work. For example, one such case read: "Albert Folc Pi.. Public Health \& General Medicine. .ass't professor, Pharmacology \& Nutricional Diseases, U. of Barcelona Medical School..chief, Dept. of Medicine, Ministry of Interior..published translations from German $\&$ English of works on endocrinology \& physiology..age 38 , married, 4 children"

The last document we found is a letter Meyer sent to Gardiner Howland Shaw (1893-1965), the Assistant Secretary of State; in it he expresses his concern for the situation surrounding Jesús Hernández Tomás's transit visa. In the following letter to the State Department on November 17, 1943, he states:
I am sending today a letter, a copy of which I enclose to the Honorable Cordell Hull, in the hope that the application for passage to his Mexican destination of Jesus Hernandez Tomas can be granted.

If there were time, I should get the fullest information from Professor Rios, the former ambassador, now at the New School for Social Research, and Dr. Lafora now in Mexico, and Dr. Amelio Mira. It would be a pity if Tomas should be the victim of any flaw of a formal character"

A few days later, on November 23, 1943, G. H. Shaw responded: "I have made inquiries with regard to the application of Jesus Hernandez Tomas for a transit visa to proceed to Mexico and understand that it is being actively considered"

And so it was, effectively. Jesús Hernández Tomás (1907-1971) arrived in Mexico toward the end of 1943. This politician had been a Minister during the Republic and had held positions of great responsibility with the Communist Party in exile, to the point of being considered as a possible successor to its Secretary, José Díaz - a position Dolores Ibarruri would ultimately fill-.

We are unaware what circumstances led Meyer to actively support this Spanish politician's application. In any case, this last letter is further testament to Meyer's concern for the plight of Spanish refugees, even long after the Spanish Civil War had ended. Although we did not find any response to Barsky's last, anguished cry regarding the position of Spanish refugees, Meyer's prolonged involvement with a particular case after the war's end, and his participation at all the meetings involving his Spanish colleagues, lead us to presume his support of the cause.

\section{Final Comments}

Meyer maintained correspondence with important figures in the history of Spanish Psychology, and that correspondence reflects precisely the Swiss psychiatrist's own concerns: his interest in the scientific foundation of clinical practice and in developing an inclusive perspective that would allow for a holistic study of mental illness, his Psychobiology, and his prominent, active role in the process of institutionalizing American psychiatry and psychology. His correspondence with Spanish scientists reflects those concerns.

Therefore, the written exchanges between Meyer and Ramón y Cajal, Achúcarro and Lafora demonstrate not only the great scientific and personal esteem in which Meyer held them, but also, for example, his interest in making Ramón y Cajal's work accessible to the American public, and his wish to get him to participate in the inaugural exercises of the Henry Phipps Psychiatric Clinic, the first modern, American psychiatric institution. On a related note, the Swiss psychiatrist's active role in nominating Lafora for membership in the American Neurological Association is 
yet another sign of the tremendous admiration Meyer felt for these Spanish scientists.

The cases of Germain and Mira are especially worthy of mention here. With respect to the first, we have learned more about the failed International Congress on Psychology in Madrid, and that while Meyer wished to participate in it, that wish was foiled by his teaching obligations. Meyer's contact with Mira, on the other hand, was of a more political nature. In fact, as his travel journal reflects, from the moment the two men met, their exchanges were of a clearly ideological bent.

Also note that in the present research, we extended our exploration to report not only on eminent authors, but on anything that could be related to the scientific and political situation in Spain. Doing so revealed a new dimension to consider as part of the historical interpretation of the times. As we believe we have made clear throughout this article, a detailed analysis of Meyer's correspondence with Spanish doctors and psychologists offers a distinctive view of these figures, the circumstances surrounding their lives, and the tragic events that occurred in Spain during and after the Civil War. Up to this point, the majority of research addressing these questions had aided in our understanding of the events from the inside, in other words, within the context of the political changes Spain suffered during that period and the consequences of those changes in terms of the emergence and growth of psychology in Spain. What was missing, however, was a view of these figures and events from the outside, that is, from the perspective of looming figures in Psychology and Psychiatry at the time, such as Adolf Meyer.

Clearly, the political circumstances in Spain interfered enormously with the developments and modernization in science achieved there during the first decades of the $20^{\text {th }}$ century. Also, it is irrefutable that the most direct and immediate consequences were endured by the authors themselves and their families. Therefore, it stands to reason that when taking account of these pages in the history of Spanish psychology, one must bear in mind the direct impact these events had on the lives and work of these scientists. It is also critical that we consider the consequences of the disintegration of the already precarious scientific framework in Spain, and how countries that received Spanish intellectuals in exile may have been affected.

That being said, throughout these pages, we have examined how other players, mostly distanced from these circumstances, played a role in them sometimes quite actively, and to great personal consequence. In this way, they became part of the narrative framework of these events. The doctor E. Barsky was a prototypical example of this; he was jailed and disqualified from practicing his profession. Also, for H. Sigerist, his political activism was an obstacle to his brilliant career in the U.S., especially when after being accused of belonging to "Communist front" organizations, the Civil Service Commission informed him he would not be eligible to work in governmental service. Sigerist left the U.S. in 1947, thereby escaping the witch hunt that began not long after, but many other American intellectuals were not so lucky. As for Meyer, his level of involvement never led him to be questioned for anti-Americanism and surely, after 1941 when he retired, his public role was only very slight. In spite of that fact, he willfully got involved in advocating for the Spanish, communist politician Jesús Hernández Tomás in 1943.

We believe that to glean a complete view of these episodes in the history of science in Spain, it is necessary to continue exploring this line of research. Future study might try and determine what effect Spanish scientists' work had on their colleagues' line of thought, and what effects the Spanish intellectual diaspora might have had on the lives and work of these other authors, perhaps less distanced from one another than it may at first appear.

Through the present research, we were able to discern how the work of Spain's first psychologists gained a great deal of recognition internationally, and not just among European and Latin American colleagues, with whom they shared greater geographical and linguistic proximity. Using Adolf Meyer's case as a prototype, we confirmed that many of his American colleagues appreciated the Spaniards' work. However, due to the vicissitudes these men went through, discussion of the scientific topics that were usually essential to Meyer's correspondence with his colleagues lost all prominence. Instead, the content and even the interlocutors were determined by the socio-political situation at hand, so these men of science all became part of, or even leading players in, History.

\section{References}

Bandrés, J., \& Llavona, R. (1996). La psicología en los campos de concentración de Franco [Psychology in Franco's concentration camps]. Psicothema, 8, 1-11.

Barsky, E. K. (2007). Alguien tenía que ayudar [Someone had to help]. In P. Carroll, \& J. D. Fernandez (Eds.), Frente al fascismo: Nueva York y la Guerra Civil Española [Facing Fascism: New York and the Spanish Civil War] (pp. 52-59). Nueva York, NY: Museo de la Ciudad de Nueva York y New York University Press.

Benison, S. (1991). Walton B. Cannon and the politics of medical science. Bulletin of the History of Medicine, 65, 234-251.

Brown, T. M., \& Fee, E. (2003). Henry E. Sigerist: Medical historian and social visionary. American Journal of Public Health, 93, 60-62.

Bustamante, M. (1982). Nicolás Achúcarro: su vida y su obra [Nicolás Achúcarro: His life and work]. Archivos de Neurobiología, 45, 55-72.

Cadwallader, T. C. (1992). The historical roots of the American Psychological Association. In R. B. Evans, V. Staudt Sexton, \& T. C. Cadwallader (Eds.). The American Psychological Association: A historical perspective (pp. 3-41). Washington, DC: APA. 
Carpintero, H. (2004). Historia de la psicología en España [History of psychology in Spain]. Madrid: Pirámide.

Carpintero, H., \& Lafuente, E. (2008). The congress that never was: The Madrid International Congress of Psychology (1936). History of Psychology, 11, 220-238.

Dosil, F. J. (2007). La JAE Peregrina [The JAE Pilgrim]. Revista de Indias, 67, 307-332.

Evans, R. B., Staudt Sexton, V., \& Cadwallader, T. C. (1992). The American Psychological Association: A historical perspective. Washington, DC: APA.

Famous Doctors Get Fordham Degrees (1912, September 12). The New York Times. Retrieved from http:/query.nytimes. $\mathrm{com} / \mathrm{mem} /$ archive-free/pdf?res $=$ F00E 12 F9395813738D DDAB0994D1405B 828DF1D3

Fee, E. (1996). The pleasures and perils of prophetic advocacy: Henry Sigerist and the politics of medical reform. American Journal of Public Health, 86, 1637-1647.

Finison, L. J. (1977). Psychologists and Spain: A historical note. American Psychologist, 32, 1080-1084.

García-Albea, E., \& Pérez-Trullen, J. M. (2003). The Spanish school of neurology and the first American case of Alzheimer's disease. Journal of the History of the Neurosciences, 12, 437-445.

Gelder, M. (2003). Adolf Meyer and his influence on British psychology. History of Psychiatry, 14, 475-508.

Grob, G. N. (1983). Mental illness and American society 1875 1940. New Jersey: Princeton University Press

González Cajal, J. (1988). Gonzalo Rodríguez Lafora: breves notas biográficas [Gonzalo Rodríguez Lafora: Biographical details in brief]. Revista de la Asociación Española de Neuropsiquiatría, 8, 675-695.

Haines, D. E. (2007). Santiago Ramón y Cajal at Clark University, 1899: his only visit to the United States. Brain Research Reviews, 55, 463-480.

Koch, S. (2006). La ruptura. Hemingway, Dos Passos y el asesinato de José Robles [The ruptura. Hemingway, Dos Passos and the murder of José Robles]. Barcelona: Círculo de Lectores.

Leys, R. (1991). Types of one: Adolf Meyer's life chart and the representation of individuality. Representations, 34, 1-28.

Leys, R., \& Evans, R. B. (1990). Defining american psychology. The correspondence between Adolf Meyer and Edward Bradford Titchener. Baltimore, MA: Johns Hopkins University Press.

Lief, A. (1948). The commonsense psychiatry of Dr. Adolf Meyer. New York, NY: McGraw-Hill.

Martí Ibáñez, F. (1958). Sigerist and Spain. Journal of the History of Medicine and Allied Sciences, 13, 244-250.

Martínez de Pisón, I. (2005). Enterrar a los muertos [Burying the dead]. Madrid: Seix Barral.

McNamara, P. J. (2008). Actitudes y activistas pro franquistas en Nueva York [Pro-Franco attitudes and activists in New York]. In P. Carroll, \& J. D. Fernandez (Eds.), Frente al fascismo: Nueva York y la Guerra Civil Española [Facing fascism: New York and the Spanish Civil War] (pp. 92-101). Nueva York, NY: Museo de la Ciudad de Nueva York y New York University Press.
Meyer, A. (1899). Psychopathology. In Clark University, Clark University 1889-1899. Decennial Celebration ( pp.144-147). Worcester MA: Norwood Press.

Montoro, L., \& Quintanilla, I. (1982). El Congreso Internacional de Psicología de Madrid [The International Congress on Psychology in Madrid]. Revista de Historia de la Psicología, 3, 223-230.

Only Brain and Grit Behind New Clinic (1912, september 13). The New York Times. Retrieved from: http://query. nytimes.com $/ \mathrm{mem} /$ archive-free $/$ pdf?res=F50811F939581 3738DDDAA0994D1405B828DF1D3

Ramón y Cajal, S. (1917/1981). Recuerdos de mi vida. Historia de mi labor cientifica. [Memories of my life. History of my scientific work] Madrid: Alianza.

Ramón y Cajal, S. (1921). Las sensaciones de las hormigas [Sensation in ants]. Real Sociedad Española de Historia Natural. Tomo extraordinario 9, 552-557

Ramon y Cajal, S. (1989). Recollections of my Life. Cambridge, MA: The MIT Press

Ruiz, G. Sánchez, N. (2006). Creo que probablemente voy a conseguir mucho más de este contacto que usted: correspondencia Meyer-Watson [I think I am probably going to get much more out of this contact than you: The MeyerWatson correspondence] (1909-1934). Revista de Historia de la Psicología, 27, 299-312.

Saiz, D., \& Saiz, M. (1996). Personajes para una historia de la psicología en España [Players in the history of psychology in Spain]. Barcelona: Pirámide.

Sánchez, N., \& Díaz, E. (2008). Adolf Meyer, Grosvernor Atterbury y la clínica psiquiátrica Henry Phipps, (..) devolviendo a la definición de hospital el significado completo de "hospitalidad" [Adolf Meyer, Grosvernor Atterbury and the Henry Phipps psychiatric clinic, bringing the complete meaning of "hospitality" back to the definition of hospital]. Revista de Historia de la Psicología, 29, 223-230.

Scull, A. (2005). Madhouse. A tragic tale of megalomania and modern medicine. London: Yale University Press.

Scull, A., \& Schulkin, J. (2009). Psychobiology, psychiatry, and psychoanalysis: The intersecting careers of Adolf Meyer, Phyllis Greenacre, and Curt Richter. Medical History, 53, 5-36.

Shorter, E. (1997) A History of psychiatry: from the Era of the Asylum to the Age of Prozac. New York, NY: John Wiley \& sons, Inc.

Sigerist, H. E. (1939). Yugoslavia and the XIth International Congress of the History of Medicine. Bulletin of the History of Medicine, 7, 99-100.

Siguan, M., \& Kirchner, M. (2001). Georges Dwelshauvers. Un psicólogo flamenco en Cataluña [Georges Dwelshauvers. A Flemish psychologist in Catalunya]. Anuario de Psicología, 32, 89-108.

Sokal, M. M. (1992). Origins and early years of the American Psychological Association: 1890 to 1906 . In R. B. Evans, V. Staudt Sexton, \& T. C. Cadwallader (Eds.). The American Psychological Association: A Historical Perspective (pp. 4371). Washington, DC: APA. 
Story. W. E., \& Wilsom, L. N. (1899). Preface. In Clark University, Clark University 1889-1899. Decennial Celebration (pp.iiiiv). Worcester, MA: Norwood Press.

Winters, E. E. (1966). Adolf Meyer's two and a half years at Kankakee. Bulletin of the History of Medicine, 43, 414-443.

Wolfe, E. L., Barger, A. C., \& Benison, S. (2000). Walter B. cannon, science and society. Cambridge, MA: Harvard University Press.
Meyer's letters and journals are deposited in the Alan Mason Chesney Medical Archives of the Johns Hopkins Medical Institutions. Letters received and rough drafts of letters sent are catalogued in Series I: Correspondence with individuals and related material. Correspondence with certain institutions and associations can be found in Series II: Correspondence with societies and other organizations. The fragment from his travel journal is part of Series VI: Biographical material and memorabilia.

Received November 10, 2010

Revision received January 21, 2011

Accepted February 03, 2011 